\title{
Allelic variation at high-molecular weight and low-molecular weight glutenin subunit genes in Moroccan bread wheat and durum wheat cultivars
}

\author{
Fatima Henkrar $^{1,2,3,4} \cdot$ Jamal El-Haddoury $^{3} \cdot$ Driss Iraqi $^{2} \cdot$ Najib Bendaou $^{4} \cdot$ \\ Sripada M. Udupa ${ }^{1}$
}

Received: 11 May 2017 / Accepted: 28 July 2017/Published online: 23 August 2017

(c) The Author(s) 2017. This article is an open access publication

\begin{abstract}
Glutenin is a major protein fraction contributing to the functional properties of gluten and dough. The glutenin constitutes $30-40 \%$ of the protein in wheat flour and about half of that in gluten. It is essential to identify correct glutenin alleles and to improve wheat quality by selecting alleles that exert favorable effects. Moroccan wheat cultivars are unique in West Asia and North Africa region, since many of them possess resistance to Hessian fly, a pest, which is becoming important in other countries in the region. Hence, these cultivars are being used as donor for the resistance in the breeding program. Here, we determine the allelic variation in high-molecular weight glutenin subunits (HMW-GS) and low-molecular weight glutenin subunits (LMW-GS) in Moroccan cultivars of bread and durum wheat using the gene-specific PCR markers. In 20 cultivars of bread wheat, 9 different allele variants were detected at HMW-GS and 13 different allele variants were detected at LMW-GS, in which the alleles Glu-Alb $(2 *)$, Glu-Bli $\quad(17+18), \quad$ Glu-Blc $(7 * / 7+9), \quad$ Glu-Dld $(5+10), G l u-A 3 c, G l u-B 3 h$, and Glu-D3b were the most frequents. In 26 cultivars of durum wheat, less allelic variation was found: seven different allele variants at HMW-GS and six different allele variants at LMW-GS
\end{abstract}

Sripada M. Udupa

s.udupa@cgiar.org; sripada.udupa@gmail.com

1 International Center for Agricultural Research in the Dry Areas (ICARDA), B.P. 6299, Rabat, Morocco

2 Biotechnology Unit, Institut National de la Recherche Agronomique (INRA), B.P. 415, Rabat, Morocco

3 Biotechnology Laboratory, Institut National de la Recherche Agronomique (INRA), B.P. 589, Settat, Morocco

4 Faculty of Sciences, Mohammed V University, Rabat, Morocco were identified, in which the major alleles were Glu-Alc (null), Glu-Blb $(7+8)$, Glu-Ble (20), Glu-A3c, and Glu$B 3 d$. The mean value of the genetic diversity for the glutenin loci was 0.502 in bread wheat and 0.449 in durum wheat. Most of the glutenin alleles carried by Moroccan bread wheat cultivars impart good bread-making quality. Most of the durum wheat glutenin alleles were related to low strength dough or poor quality and need to be improved. To improve quality of Moroccan durum wheat, essentially, Glu-Alc and Glu-B3d alleles of the genes should be replaced with the better alleles through breeding.

Keywords Moroccan wheat - Glutenin - HMW-GS . LMW-GS · PCR markers · End-use quality

\section{Introduction}

Glutenin proteins are the most important protein group which determines bread-making quality of bread wheat (Triticum aestivum L.) and pasta making quality of durum wheat (Triticum turgidum L.). It contributes to the ability of dough to rise and maintain its shape as it is baked. Glutenin strength differs with varieties of wheat. It is highly heterogeneous mixture of polymers consisting of a number of different high- and low-molecular-weight glutenin subunits (HMW-GSs and LMW-GSs) linked by disulfide bonds (Veraverbeke and Delcour 2002), resulting in variability in gluten strength among wheat varieties.

The HMW-GSs comprise about $20-30 \%$ of the glutenin (Shan et al. 2003) and play a key role in determining wheat gluten and dough elasticity. The HMW-GSs presented a high level of polymorphism. Therefore, the HMW-GSs are of immense importance in wheat breeding and genetics. A complex locus Glu-1 encodes HMW-GS. Glu-1 complex 
loci located on the long arm of chromosomes from homeologous group 1 and called Glu-A1, Glu-B1, and GluDl (Shewry et al. 1992). In each chromosome, the Glu-1 locus contains two closely linked genes that encode for $\mathrm{x}$-type glutenin subunit and y-type glutenin subunit polypeptides (Shewry et al. 1992). The LMW-GSs are quantitatively the major class of glutenin subunits which accounts for about $70-80 \%$ of the glutenins. The LMW-GS showed large effects on dough extensibility (Gianibelli et al. 2001) and gluten strength (Cornish et al. 2001) and thus influences the quality of end-use products of wheat (Gupta et al. 1990, 1991; He et al. 2005). The LMW-GSs are encoded by Glu-3 loci on the short arms of homeologous group 1 and called $G l u-A 3, G l u-B 3$, and $G l u-D 3$ in bread wheat (Gupta and Shepherd 1990; Jackson et al. 1983; Masci et al. 2002). Glu-3 locus is a multigene family closely linked to the Gli-l loci containing genes encoding $\omega$ and $\gamma$ gliadins.

Previous studies revealed that different alleles of HMWGS or LMW-GS could have similar mobilities using SDSPAGE, resulting in the incorrect identification of some alleles that are functionally different, such as $\mathrm{Ax} 2$ and $\mathrm{Ax} 2 *$, $\mathrm{Bx} 7$ and $\mathrm{Bx} 7 *$, By8 and By8*, Bx14-By15, and Bx20 for HMW-GS, and several alleles overlapping for LMW-GS. Hence, characterization of HMW-GS and LMW-GS genes at the DNA level and development of functional markers are needed for the discrimination of different-alleles in wheat breeding. In wheat, many functional markers are developed for the glutenin loci. The PCR-based markers are available to discriminate the important Glu-1 alleles Dx5, Dy10, Ax2*, Bx7, Bx7*, Bx17, By8, and By9 (Ahmad 2000; Ma et al. 2003; Butow et al. 2004; Lei et al. 2006). Similarly, several markers are designed to differentiate the Glu-3 alleles at GluA3, Glu-B3, and Glu-D3 (Zhang et al. 2004; Zhao et al. 2007a, b; Wang et al. 2009).

In Morocco, several bread wheat and durum wheat cultivars have been released over the years. In recent years, bread wheat and durum wheat cultivars with the Hessian fly (Lhaloui et al. 2000, 2005) resistance have been developed and released for cultivation to tackle this pest problem in arid and semi-arid regions. Arrihane and Aguilal varieties of bread wheat were released in 1998. For durum wheat, the varieties Irden, Nassira, Chaoui, and Amria were released in 2003, Marouane in 2005, and Icamor in 2006. These resistant cultivars are useful donors for other countries in the North Africa and West Asia regions, where the Hessian fly is emerging as an important pest in recent times. However, these cultivars are not yet characterized for HMW-GS and LMW-GS variability, which is useful for marker-assisted selection in the breeding when those cultivars used as parents in the breeding program.

In Morocco, some studies were realized on the allelic variation in prolamin protein, namely, glutenin and gliadin.
Using SDS-PAGE, Bakhella and Branlard (1997) observed the predominance of subunit $2 *-5-17-18-10$ in 44 Moroccan bread wheat cultivars and landraces, and predominance of 6-8 and 20 in 39 Moroccan durum wheat cultivars and landraces with respect to HMW-GS. In that abstract, no details regarding the landraces or cultivars used and their HMW-GS alleles were available. Zarkti et al. (2010) using also SDS-PAGE for characterization HMWGS and LMW-GS of 23 Moroccan durum wheat landraces reported that the majority of the landraces possess the null subunit at Glu-Al and $20 x+20 y$ at Glu-Bl. However, information on HMW-GS and LMW-GS variability in the Moroccan cultivars of bread wheat and durum wheat is not available. Thus, the objective of the present study was to determine the allelic variation at $G l u-1$ and $G l u-3$ glutenin loci in 20 Moroccan bread and 26 Moroccan durum wheat cultivars released until 2006 using gene-specific PCR markers. The allelic information at Glu-1 and Glu-3 glutenin loci based on PCR-based technique, a non-destructive method, will be helpful for transferring useful alleles through genomic-assisted improvement of wheat.

\section{Materials and methods}

\section{Plant materials}

Total of 20 bread wheat and 21 durum wheat varieties (Table 1; Henkrar et al. 2015a, b) and 5 additional durum wheat varieties, Isly (released in 1988), Massa (released in 1988), Anouar (released in 1993), Sboula (released in 2000), and Chaoui (released in 2003) were used to characterize the glutenin alleles at $G l u-A 1, G l u-B 1, G l u-D 1, G l u-A 3, G l u-B 3$, and $G l u-D 3$ loci. Five exotic cultivars with known glutenin subunit composition (Tables 1,2) were used as controls to confirm the exact fragment amplified.

\section{DNA extraction and gene-specific marker analysis}

Genomic DNA was extracted from leaves at seedling stage using a CTAB (cetyltrimethylammonium bromide) protocol of Saghai-Maroof et al. (1984) with slight modification (Udupa et al. 1999). Quality and quantity of the isolated DNA were determined on $1.0 \%(\mathrm{w} / \mathrm{v})$ agarose gels by comparing bands to known concentrations of lambda DNA. The PCR reactions were performed in a total volume of $10 \mu \mathrm{L}$, containing 1X PCR buffer (Promega, USA), $1.5 \mathrm{mM} \mathrm{MgCl}, 200 \mu \mathrm{M}$ of each dNTPs, 10 pmol of each primer, $0.5 \mathrm{U}$ of $\mathrm{Taq}$ DNA polymerase, and approximately $50 \mathrm{ng}$ of genomic DNA. All the allele-specific and genespecific PCR primers were synthesized (Sigma-Genosys, Germany) according to published sequence information: Ax2*/Ax1/Axnull (Lafiandra et al. 1997), Ax2* (De Bustos 
Table 1 HMW-GS composition of exotic cultivars used in this study as controls

\begin{tabular}{|c|c|c|c|c|c|}
\hline Cultivar & Glu-A1 & Glu-B1 & Glu-D1 & Alleles & References \\
\hline Chinese-Spring & & $7+8$ & $2+12$ & $c, b, a$ & Bekes et al. (2008a) \\
\hline Annuello & 1 & $7 *+8$ & $2+12$ & $a, u, a$ & Bekes et al. (2008a) \\
\hline Pavon-76 & $2 * / 1$ & $17+18$ & $5+10$ & $b / a, i, d$ & Bekes et al. (2008a) \\
\hline Stylet & 1 & $7+9$ & $5+10$ & $a, c, d$ & Bekes et al. (2008a) \\
\hline Yecora-Rojo & 1 & $17+18$ & $5+10$ & $a, i, d$ & Bekes et al. (2008a) \\
\hline
\end{tabular}

Table 2 LMW-GS composition of exotic cultivars used in this study as controls

\begin{tabular}{lllll}
\hline Cultivar & GluA3 & GluB3 & GluD3 & References \\
\hline Chinese-Spring & $a$ & $a$ & $a$ & Bekes et al. (2008b) \\
Annuello & $b$ & $b$ & $b$ & Bekes et al. (2008b) \\
Pavon-76 & $b$ & $h$ & $e ?$ & Bekes et al. (2008b) \\
Stylet & $c / e$ & $h$ & $c$ & Bekes et al. (2008b) \\
Yecora-Rojo & $d$ & $h$ & $a$ & Bekes et al. (2008b) \\
\hline
\end{tabular}

et al. 2000), Dx5/Dx2, Dy10/Dy12, and Bx7 (Ahmad 2000), Bx/Bx7*/Bx6 (Butow et al. 2004), By8/By8*/By9/ By18*/By20* (Lei et al. 2006), Glu-A3 (Zhang et al. 2004), Glu-B3 (Wang et al. 2009), and Glu-D3 (Zhao et al. $2007 \mathrm{a}, \mathrm{b})$. The amplification programs and electrophoresis conditions of the PCR assays were based on the references mentioned above. The PCR products were separated in ethidium bromide-stained 1.2 or $1.5 \%$ (w/v) agarose gels run in $1 \times$ TBE buffer and exposed to UV light to visualize DNA fragments.

\section{Statistical analysis}

The gene diversity, number of alleles, and PIC value were calculated using the PowerMarker software (Ver. 3.0; Liu and Muse 2005). The glutenin relationship between cultivars was visualized as a dendrogram using the PowerMarker and MEGA5 software (Tamura et al. 2011). The Neighbor-joining tree was constructed using the frequencybased distance for the shared allele.

\section{Results}

\section{Allelic variation in bread wheat cultivars}

HMW-GS and LMW-GS composition of 20 Moroccan bread wheat cultivars based on gene/allele-specific PCR analysis are shown in Table 3 . The frequencies of different alleles identified were calculated and schematized in Fig. 1.

A total of nine different allele variants were detected at HMW-GS. Three subunits $(1,2 *$, and null) were identified at $G l u-A l$ locus, and the sum of the frequency of the two active types $1(G l u-A l a)$ and $2 *(G l u-A 1 b)$ was $85 \%$. While the rest were null-type gene $G l u-A 1 c$. There were four subunit pairs at $G l u-B 1$ locus $7 *-8(G l u-B 1 u), 7-8 *$ (Glu-Blal), 7/7*-9 (Glu-Blc), and 17-18 (Glu-Bli). Among them, the subunit pairs $7 / 7^{*}-9$ and $17-18$ had highest proportion, $35 \%$ for each. At Glu-D1 locus, the predominant HMW-GS were the combination 5-10 (Glu$D 1 d$ ) at frequency of $85 \%$. Then, $15 \%$ were for the combination 2-12 (Glu-Dla).

In LMW-GS, 13 different allele variants were identified. At $G l u-A 3$ locus, five alleles were found $(b, c, d, e$, and i) among which $G l u-A 3 c$ occurred in $50 \%$ of the cultivars. Glu-B3 appears to be highly polymorphic in this set of cultivars. Out of the six alleles ( $b, f g, g, i, h$, and $j)$, alleles Glu-B3h and Glu-B3i were predominant and showed a high frequency of 35 and 29\%, respectively. The cultivars Nasma, Rajae, and Salama did show any alleles using the available allele-specific PCR markers for Glu-B3. This indicates that these cultivars had other allele types, not able to be identified using the present PCR markers and involve the SDS-PAGE technique. In addition, no allele was amplified in variety Tilila using the same set of allelespecific primers. The variety Tilila had a 1BL.1RS translocation and was derived from Veery "s" (Jlibene et al. 1996), which has been characterized to have the allele $j$ (Gupta et al. 1994). Furthermore, according to Gupta et al. (1994), the allele $G l u-B 3 j$ is associated with the translocated chromosome1BL.1RS. Thus, Tilila had the allele Glu-B3j. At Glu-D3 locus, two alleles were identified, Glu$D 3 a$ and $G l u-D 3 b$ with a frequency of 5 and $95 \%$, respectively. 
Table 3 HMW-GS and LMW-GS composition in Moroccan bread wheat cultivars using gene-specific PCR markers

\begin{tabular}{|c|c|c|c|c|c|c|}
\hline \multirow[t]{2}{*}{ Cultivar } & \multicolumn{3}{|c|}{ HMW-GS } & \multicolumn{3}{|c|}{ LMW-GS } \\
\hline & Glu-A1 & Glu-B1 & Glu-D1 & Glu-A3 & Glu-B3 & Glu-D3 \\
\hline Saïs & $1(a)$ & $7 *-8(u)$ & $5-10(d)$ & $b$ & $i$ & $b$ \\
\hline Arrehane & $2 *(b)$ & $17-18(i)$ & $5-10(d)$ & $b$ & $i$ & $b$ \\
\hline Acsad-59 & null $(c)$ & $7 *-8(u)$ & $5-10(d)$ & $c$ & $b$ & $b$ \\
\hline Kanz & $2 *(b)$ & $17-18(i)$ & $5-10(d)$ & $f$ & $h$ & $b$ \\
\hline Aguilal & $1(a)$ & $7 *-8(u)$ & $5-10(d)$ & $d$ & $i$ & $b$ \\
\hline Tilila & $1(a)$ & $7 *-9(c)$ & $5-10(d)$ & $c$ & $j$ & $b$ \\
\hline Achtar & $2 *(b)$ & $17-18(i)$ & $5-10(d)$ & $c$ & $f g$ & $b$ \\
\hline Nasma & $2 *(b)$ & $7 *-8(u)$ & $5-10(d)$ & $c$ & - & $b$ \\
\hline Khair & $2 *(b)$ & $7-8^{*}(a l)$ & $2-12(a)$ & $b$ & $f g$ & $b$ \\
\hline Massira & null $(c)$ & $17-18(i)$ & $2-12(a)$ & $c$ & $h$ & $b$ \\
\hline Mehdia & $2 *(b)$ & $7 *-9(c)$ & $5-10(d)$ & $c$ & $h$ & $b$ \\
\hline Rajae & $2 *(b)$ & $17-18(i)$ & $5-10(d)$ & $c$ & - & $b$ \\
\hline Amal & $2 *(b)$ & $7 *-9(c)$ & $5-10(d)$ & $f$ & $g$ & $b$ \\
\hline Baraka & $2 *(b)$ & $17-18(i)$ & $2-12(a)$ & $b$ & $i$ & $b$ \\
\hline Jouda & $1(a)$ & $17-18(i)$ & $5-10(d)$ & $c$ & $h$ & $b$ \\
\hline Saba & null $(c)$ & $7 * \_9(c)$ & $5-10(d)$ & $c$ & $g$ & $b$ \\
\hline Marchouch & $2 *(b)$ & $7 *-8(u)$ & $5-10(d)$ & $b$ & $h$ & $b$ \\
\hline Potam & $2 *(b)$ & $7 * \_9(c)$ & $5-10(d)$ & $c$ & $i$ & $b$ \\
\hline Saada & $1(a)$ & $7 *-9(c)$ & $5-10(d)$ & $f$ & $h$ & $a$ \\
\hline Salama & $2 *(b)$ & $7 *-9(c)$ & $5-10(d)$ & $e$ & - & $b$ \\
\hline
\end{tabular}

\section{Allelic variation in durum wheat cultivars}

The HMW-GS and LMW-GS compositions of 26 Moroccan durum wheat cultivars are summarized in Table 4 and their frequencies are presented in Fig. 1. Less allelic variation was found in the Moroccan durum wheat compared to the bread wheat: six different allele variants at Glu-1 (HMW-GS) and seven allele variants at Glu-3 (LMW-GS). At $G l u-A 1$, the null type was present in all cultivars studied $(100 \%)$, and no active type was detected. Five alleles identified at Glu-Bl loci, with subunits 6-8 (Glu-Bld), 7-8 (Glu-Blb), 7/7*-9 (Glu-B1c), 17-18 (Glu-Bli), and 20 (Glu-Ble), in which the subunit pairs 7-8 and 20 were the predominant with 38 and $35 \%$, respectively. Among the three alleles detected at $G l u-A 3$ loci, Glu-A3c was the most frequent (62\%). The Glu-B3 locus exhibited four alleles ( $d$, $i$, $g$, and $h$ ) and Glu-B3d was the major allele with high frequency of $58 \%$. In this locus, Oum-Rabia, Tensift, and Icamor did show any allele using the available PCR markers.

\section{Genetic diversity}

The mean value of the gene diversity for the glutenin loci was 0.502 in bread wheat and 0.449 in durum wheat. Furthermore, the gene diversity of the individual loci varied widely (Table 5). The lowest value was 0.095 showed at $G l u-D 3$ locus that exhibited only two different alleles $a$ and $b$ in bread wheat and 0 at Glu-Al locus in durum wheat due to the overwhelming presence of the nulltype gene Glu-Alc. The highest value was 0.770 at $G l u-B 3$ in bread wheat and 0.701 at $G l u-B 1$ in durum wheat. The neighbor-joining dendrogram (Fig. 2) clustered the two species in separated groups. The bread wheat cultivars were highly divergent than the durum wheat cultivars.

\section{Discussion}

HMW-GS variations in some old varieties and landraces of bread wheat and durum wheat from Morocco were previously investigated using SDS-PAGE technique (Bakhella and Branlard, 1997). Zarkti et al. (2010) studied HMW-GS and LMW-GS variation in 23 local landraces of durum wheat using SDS-PAGE technique. The SDS-PAGE base technique is destructive and can be carried out only after the harvest of the grains and may not be handy for markerassisted selection.

However, the HMW-GS and LMW-GS variations in the recently released bread wheat and durum wheat varieties from Morocco are lacking. Moreover, all the previous works on HMW-GS and LMW-GS variability in Moroccan 
Fig. 1 Frequency of alleles at different Glu loci in the 20 Moroccan bread wheat cultivars (a) and 26 Moroccan durum wheat cultivars (b)

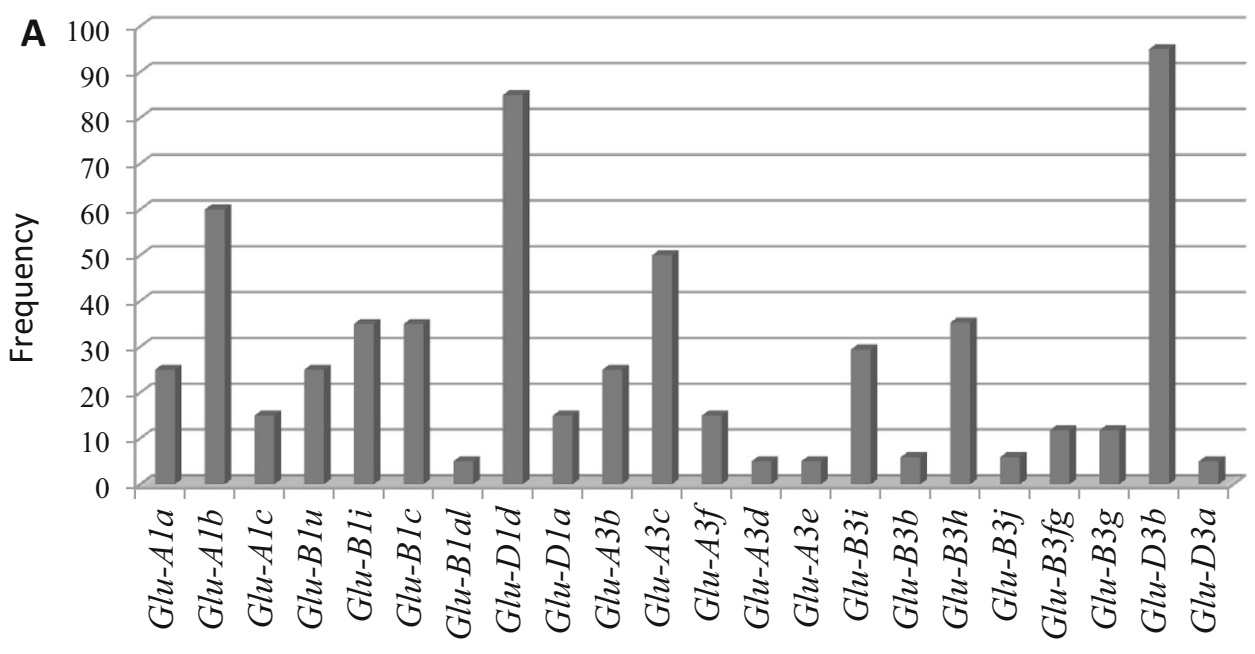

Alleles at different Glu loci in Moroccan bread wheat

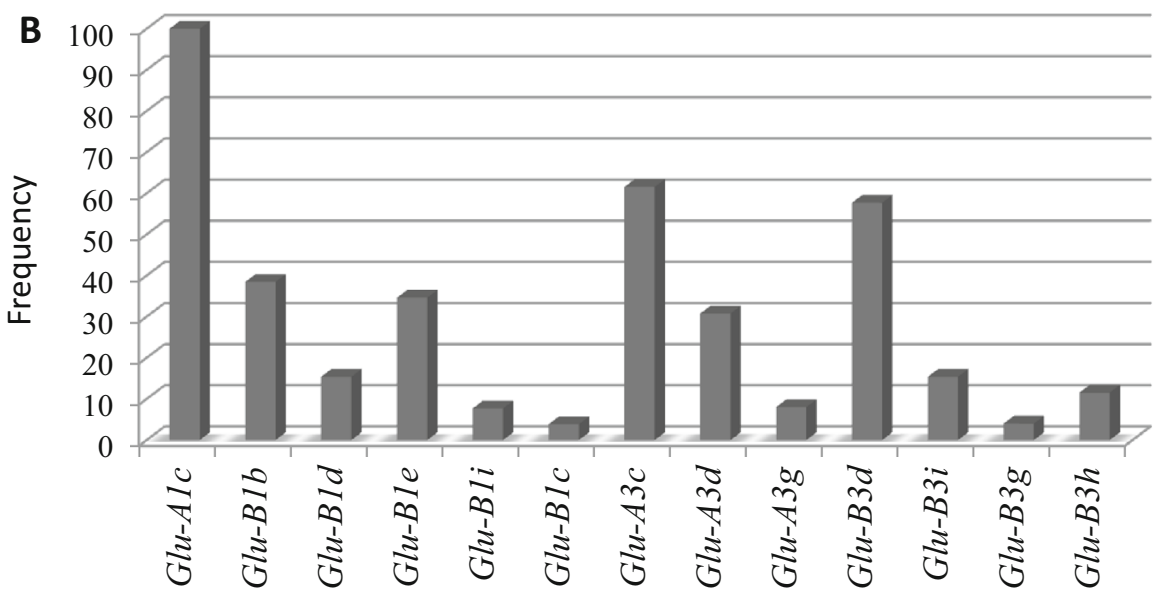

Alleles at different Glu loci in Moroccan durum wheat wheat varieties were based on SDS-PAGE technique, which uses the harvested grains and destructive and is not useful for making selection at early stage of plant growth.

In this study, we analyzed the allelic variation of HMWGS and LMW-GS glutenin loci in the 20 bread wheat and 26 durum wheat varieties representing the most important and recently developed cultivars in Morocco using gene/ allele-specific PCR. Many of the recently developed varieties carry resistance to the Hessian fly, which is an important pest in semi-arid regions of Morocco. Because of climate change, the problem of this pest is spreading to other areas in Morocco, the North Africa and many other wheat-producing countries. The Moroccan varieties could be used as donors in wheat presumptive breeding in many counties in the semi-arid regions. Therefore, knowledge of allelic variation at $G l u-1$ and $G l u-3$ loci is very important for selection of suitable parents for crossing and marker- assisted selection of the Hessian resistance and better enduse quality (Henkrar et al. 2016).

Alleles present at each of the Glu-1 and Glu-3 loci can have a large combined effect on dough properties and suitability for specific end-products (Appelbee 2007; Eagles et al. 2006; Gupta et al. 1994). With correct classification of glutenin alleles, it is possible to improve wheat quality by selecting alleles that exert favorable effects and allelic combinations (Eagles et al. 2002). Therefore, in this study, we revealed the allelic variation of HMW-GS and LMW-GS glutenin subunit composition in 46 Moroccan wheat cultivars using PCR markers. 9 different allele variants at HMW-GS and 13 different allele variants at LMW-GS were identified in 20 cultivars of bread wheat. Six different allele variants at HMW-GS and seven allele variants at LMW-GS were noticed in 26 cultivars of durum wheat.

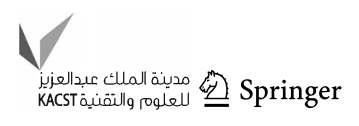


Table 4 HMW-GS and LMW-GS composition in Moroccan durum wheat cultivars using gene-specific PCR markers

\begin{tabular}{|c|c|c|c|c|}
\hline \multirow[t]{2}{*}{ Cultivar } & \multicolumn{2}{|c|}{ HMW-GS } & \multicolumn{2}{|c|}{ LMW-GS } \\
\hline & Glu-A1 & Glu-B1 & Glu-A3 & Glu-B3 \\
\hline Karim & null $(c)$ & $7-8(b)$ & $c$ & $d$ \\
\hline Ourgh & null $(c)$ & $7-8(b)$ & $c$ & $d$ \\
\hline Oum-Rabia & null $(c)$ & $7-8(b)$ & $c$ & - \\
\hline Sarif & null $(c)$ & $6-8(d)$ & $c$ & $i$ \\
\hline Amjad & null $(c)$ & $20(e)$ & $c$ & $d$ \\
\hline Marzak & null $(c)$ & $7-8(b)$ & $d$ & $d$ \\
\hline Jawhar & null $(c)$ & $20(e)$ & $c$ & $d$ \\
\hline Anouar & null $(c)$ & $7-8(b)$ & $c$ & $g$ \\
\hline Massa & null $(c)$ & $7-8(b)$ & $c$ & $h$ \\
\hline Isly & null $(c)$ & $6-8(d)$ & $d$ & $d$ \\
\hline Sebou & null $(c)$ & $17-18(i)$ & $d$ & $d$ \\
\hline Tensift & null $(c)$ & $20(e)$ & $c$ & - \\
\hline Merjana & null $(c)$ & $7-8(b)$ & $c$ & $d$ \\
\hline Tomouh & null $(c)$ & $20(e)$ & $c$ & $d$ \\
\hline Tarek & null $(c)$ & $6-8(d)$ & $c$ & $d$ \\
\hline Belbachir & null $(c)$ & $7-8(b)$ & $c$ & $d$ \\
\hline Icamor & null $(c)$ & $20(e)$ & $c$ & - \\
\hline Maroune & null $(c)$ & $7-8(b)$ & $d$ & $h$ \\
\hline Nassira & null $(c)$ & $7 *-9(c)$ & $c$ & $d$ \\
\hline Chaoui & null $(c)$ & $20(e)$ & $d$ & $i$ \\
\hline Amria & null $(c)$ & $20(e)$ & $d$ & $i$ \\
\hline Cocorit & null $(c)$ & $6-8(d)$ & $g$ & $h$ \\
\hline Irden & null $(c)$ & $20(e)$ & $d$ & $i$ \\
\hline Kyperonda & null $(c)$ & $17-18(i)$ & $d$ & $d$ \\
\hline Sboula & null $(c)$ & $7-8(b)$ & $c$ & $d$ \\
\hline Selbera & null $(c)$ & $20(e)$ & $g$ & $d$ \\
\hline
\end{tabular}

Table 5 Number of alleles, Gene diversity and PIC value of HMWGS and LMW-GS in Moroccan bread and durum wheat cultivars

\begin{tabular}{llllllll}
\hline Marker & \multicolumn{2}{l}{ Bread wheat } & & \multicolumn{2}{l}{ Durum wheat } \\
\cline { 2 - 3 } & $\begin{array}{l}\text { No. of } \\
\text { alleles }\end{array}$ & $\begin{array}{l}\text { Gene } \\
\text { diversity }\end{array}$ & PIC & & $\begin{array}{l}\text { No. of } \\
\text { alleles }\end{array}$ & $\begin{array}{l}\text { Gene } \\
\text { diversity }\end{array}$ & PIC \\
\hline Glu-A1 & 3 & 0.555 & 0.491 & 1 & 0 & 0 \\
Glu-B1 & 4 & 0.690 & 0.628 & 5 & 0.701 & 0.649 \\
Glu-D1 & 2 & 0.255 & 0.222 & - & - & - \\
Glu-A3 & 5 & 0.660 & 0.611 & 3 & 0.541 & 0.465 \\
Glu-B3 & 6 & 0.754 & 0.717 & 4 & 0.555 & 0.515 \\
Glu-D3 & 2 & 0.095 & 0.090 & - & - & - \\
Mean & 3.667 & 0.502 & 0.460 & 3.250 & 0.449 & 0.407 \\
\hline
\end{tabular}

\section{Allelic variation in bread wheat cultivars}

The HMW-GS composition $2 *(b), 7 / 7 *-9(c), 17-18(i)$, and 5-10 (d) was the most frequent. Odenbach and

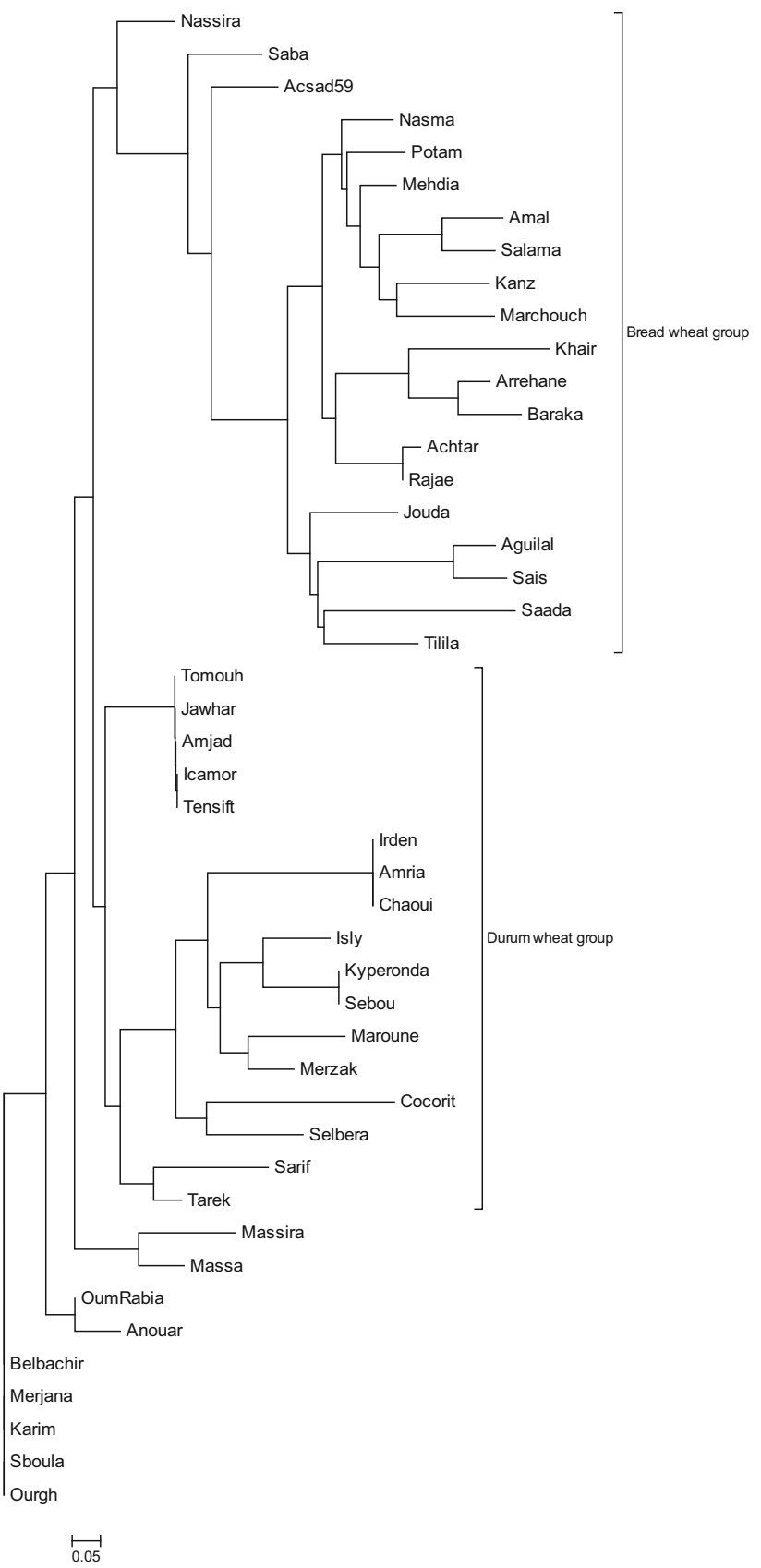

Fig. 2 Dendrogram obtained by neighbor-joining method based on shared allele genetic distance estimates of 20 bread wheat and 26 durum wheat cultivars

Mahgoub (1988) found that the HMW glutenin subunits $2^{*}, 7+9$, and $5+10$ were associated with large sedimentation volumes. Ram (2003) reported also that the combination of Glu-Alb, Glu-Bli, and Glu-Dld alleles exhibited the highest dough strength and can be used as combination to improve bread-making quality. For Glu-Al locus, the two active types of HMW-GS 1 and $2 *$ were detected at high frequency (85\%) which appears to be a better baking quality allele and confers better values for the 
quality parameters than allele null (Luo et al. 2001). The same subunit had been previously described by Giraldo et al. (2010) in set of Spanish wheat landraces. Likewise, the same subunit had been found in Argentinean bread wheat (Lerner et al. 2009). However, these results are quite different to those observed in China and French bread wheat, where the allele Glu-Alc (null type) was the most frequent (Yan et al. 2007; Branlard et al. 2003).

For Glu-B1 locus, four alleles were detected. The most frequent alleles were 7/7*-9 $(\mathrm{Glu}-\mathrm{Blc})$ and 17-18 (Glu$B 1 i)$. Both alleles have high sedimentation volume, but allele 17-18 (Glu-B1i) has greater effect on sedimentation and mixograph (Carrillo et al. 1990b; Ram 2003). The allele Glu-Bla which affects negatively the dough properties was not detected in our cultivars. Previous studies reported the predominance of allele 7-9 $($ Glu-Blc) in varieties from US, Argentina and Pakistan (Shan et al. 2007; Lerner et al. 2009; Tabasum et al. 2011). Ma et al. (2003) identified that alleles 17-18 (Glu-Bli) and 7-8 $(G l u-B 1 b)$ were the major alleles in Australian wheat. In the bread wheat varieties of France and China, allele 7-8 $(G l u-B 1 b)$ was the most predominant (Yan et al. 2007; Branlard et al. 2003).

At Glu-Dl, Payne (1987) proved that allelic variation at Glu-D1 locus had greater effects than other loci on breadmaking quality. According to Gupta et al. $(1989,1994)$, subunit combination $5+10$ is associated with good breadmaking quality, whereas subunit combination $2+12$ associated with poor bread-making quality. $85 \%$ of cultivars studied possessed combination $5+10$ (Glu-Dld). Similar allelic distribution discovered in Argentinean bread wheat (Lerner et al. 2009). Nevertheless, studies on Spanish, French or Asian bread wheat (Giraldo et al. 2010; Yan et al. 2007; Terasawa et al. 2011) have reported the predominance of $2+12$.

For LMW-GS, the Glu-3 alleles have been already ranked according to their $\mathrm{R}_{\max }$ (maximum dough resistance). The Glu-A3 alleles ranked as $b>d>e>c$, the Glu-B3 alleles ranked as $i>b=a>e=f=g=$ $h>c$ and the Glu-D3 alleles ranked as $e>b>a>c>d$ (Gupta and Shepherd 1988; Gupta et al. 1989, 1990, 1994; Gupta and MacRitchie 1994; Metakovsky et al. 1990). In the examined cultivars, the allele Glu-A3c represented $50 \%$, and according to $R_{\max }$, this allele is associated with low dough resistance and ranked poor quality. Lerner et al. (2009) and Shan et al. (2007) found also similar results and predominance of allele $c$ at Glu-A3 locus in Argentinean and US bread wheat cultivars. At $G l u-B 3$, the alleles $G l u-B 3 h$ and $G l u-B 3 i$ were the most frequent. The allele $G l u-B 3 i$ is associated with high gluten strength, while allele $G l u-B 3 h$ is related to intermediate gluten quality. Comparing the Glu-B3 variation with other studies, our results is totally different to the results of US,
Argentinean and French wheat in which the allele $g$ was the most frequent (Shan et al. 2007; Lerner et al. 2009; Giraldo et al. 2010). The allelic variation at the Glu-D3 was limited to the presence of two alleles Glu-D3a and Glu-D3b. The allele Glu-D3b was the major allele in Moroccan bread wheat $(95 \%)$ and generally reported to be associated with good quality (Lerner et al. 2009). This result is similar to the results of Argentinean and US wheat (Lerner et al. 2009; Shan et al. 2007), but different to those observed in French wheat were the allele Glu-D3c was the predominant.

\section{Allelic variation in durum wheat cultivars}

The null-type gene Glu-Alc related to less extensible or medium elastic dough (Branlard et al. 2003) was the only allele present in the 26 cultivars of durum wheat. The Glu$B 1 b, G l u-B 1 e$, and Glu-Bld were predominant with 38,35 , and $15 \%$, respectively. $G l u-B 1 b$ is considered the best allele in relation to quality; Glu-B1d slightly poorer than Glu-Blb and Glu-Ble is considered the poorest (Carrillo et al. 1990a). Like in the bread wheat, the predominant allele at $G l u-A 3$ was allele c with $61 \%$ in the durum wheat cultivars of Morocco. At the Glu-B3 locus, the allele Glu$B 3 d$ was the most frequent (65\%) which had a medium to weak dough properties (Cornish et al. 1993; Luo et al. 2001). For the $G l u-A 3$ and $G l u-B 3$, our results were quite different from the Spanish durum landraces (Aguiriano et al. 2008), in which they reported the predominance of allele $a$ for both locus. Compared to bread wheat, durum wheat was less variable in glutenin alleles.

\section{Conclusion}

The results obtained in this report describing the allelic compositions of Moroccan bread and durum wheat cultivars may have high allelic variability. From this analysis, two points were important. Our results obtained using PCR markers are similar to those reported previously by Bakhella and Branlard (1997) and Zarkti et al. (2010) for HMW-GS proteins in which they use SDS-PAGE. Hence, this study proves the efficiency of molecular markers to identify the correct glutenin alleles, in a non-destructive way. In general, Moroccan bread wheat cultivars carried alleles associated to good bread-making quality. However, in durum wheat cultivars, most of the alleles related to low strength dough and need to be improved. Even though many of the durum wheat cultivars and some of the bread wheat cultivars having genes for resistance to the Hessian fly could be used as donors in the breeding program, the glutinin alleles such as Glu-Alc and Glu-B3d should be avoided during selection in the breeding program. 
Acknowledgements The authors are grateful to the International Treaty for Plant Genetic Resources for Food and Agriculture/FAO, the European Union, the CRP-Wheat (http://wheat.org) and ICARDA/Morocco Collaborative Grants Program for the financial support. The views expressed herein can in no way be taken to reflect the official opinion of the European Union.

\section{Compliance with ethical standards}

Conflict of interest The authors declare that they have no conflict of interest in the publication.

Ethical standards The experiment complies with the ethical standards as per the current laws of Morocco in which it was performed.

Open Access This article is distributed under the terms of the Creative Commons Attribution 4.0 International License (http:// creativecommons.org/licenses/by/4.0/), which permits unrestricted use, distribution, and reproduction in any medium, provided you give appropriate credit to the original author(s) and the source, provide a link to the Creative Commons license, and indicate if changes were made.

\section{References}

Aguiriano E, Ruiz M, Fité R, Carrillo JM (2008) Genetic variation for glutenin and gliadins associated with quality in durum wheat (Triticum turgidum L. ssp. turgidum) landraces from Spain. Span J Agric Res 6:599-609. doi:10.5424/sjar/2008064-353

Ahmad M (2000) Molecular marker-assisted selection of HMW glutenin alleles related to wheat bread quality by PCR-generated DNA markers. Theor Appl Genet 101:892-896. doi:10.1007/ s001220051558

Appelbee M-J (2007) Quality potential of gluten proteins in hexaploid and related wheat species. PhD thesis, University of Adelaide, Australia

Bakhella M, Branlard G (1997) High-molecular-weight glutenin subunits composition of Moroccan durum and common wheatvarieties. Sci des Aliment 17:487-496

Bekes F, Cavanagh CR, Martinov S, Bushuk S, Wrigley CWF (2008a) The gluten composition of wheat varieties and genotypes PART II. Composition table for the HMW subunits of glutenin, 3rd edn. http://www.aaccnet.org/initiatives/definitions/ Documents/GlutenFree/II_HMW_Subunits.pdf

Bekes F, Wrigley CWF, Cavanagh CR, Martinov S, Bushuk S (2008b) The Gluten Composition of Wheat Varieties and Genotypes PART III. Composition table for the LMW subunits of glutenin, 3rd edn, AACC International. http://www.aaccnet. org/initiatives/definitions/Documents/GlutenFree/III_LMW_ Subunits.pdf. Accessed 26 July 2017

Branlard G, Dardevet M, Amiour N, Igrejas G (2003) Allelic diversity of HMW and LMW subunits and omega gliadins in French bread wheat (Triticum aestivum L). Genet Resour Crop Evol 50:669-679. doi:10.1023/A:1025077005401

Butow BJ, Gale KR, Ikea J, Juhász A, Bedö Z, Tamás L, Gianibell MC (2004) Dissemination of the highly expressed $B x 7$ glutenin subunit (Glu-Blal allele) in wheat as revealed by novel PCR markers and RP-HPLC. Theor Appl Genet 109:1525-1535. doi:10.1007/s00122-004-1776-8

Carrillo JM, Vazquez JF, Orellana J (1990a) Relationship between gluten strength and glutenin proteins in durum wheat cultivars. Plant Breed 104:325-333. doi:10.1111/j.1439-0523.1990.tb00443.x

Carrillo JM, Rousset M, Qualset CO, Kasarda DD (1990b) Use of recombinant inbred lines of wheat for study of associations of high-molecular-weight glutenin subunit alleles to quantitative traits 1. Grain yield and quality prediction tests. Theor Appl Genet 79:321-330. doi:10.1007/BF01186074

Cornish GB, Burridge PM, Palmer GA, Wrigley CW (1993) Mapping the origins of some HMW and LMW glutenin subunit alleles in Australian wheat germplasm. In: Wrigley CW (ed) Proceedings of 43rd Australian Cereal Chemistry Conference, Royal Australian Chemical Institute, Melbourne, Australia, pp 255-260

Cornish GB, Békés F, Allen HM, Martin JM (2001) Flour proteins linked to quality traits in an Australian doubled haploid wheat population. Aust J Agr Res 52:1339-1348. doi:10.1071/ AR01060

De Bustos A, Rubio P, Jouve N (2000) Molecular characterization of the inactive allele of the gene Glu-Al and the development of a set of AS-PCR markers for HMW glutenins of wheat. Theor Appl Genet 100:1085-1094. doi:10.1007/s001220051390

Eagles HA, Hollamby GJ, Gororo NN, Eastwood RF (2002) Estimation and utilisation of glutenin gene effects from the analysis of unbalanced data from wheat breeding programs. Aust J Agr Res 53:367-377. doi:10.1071/AR01074

Eagles HA, Cane K, Eastwood RF, Hollamby GJ, Kuchel H, Martin PJ, Cornish GB (2006) Contributions of glutenin and puroindoline genes to grain quality traits in southern Australian wheat breeding programs. Aust J Agr Res 57:179-186. doi:10.1071/ AR05242

Gianibelli MC, Gupta RB, Lafiandra D, Margiotta B, MacRitchie F (2001) Polymorphism of high Mr glutenin subunits in Triticum tauschii: characterization by chromatography and electrophoresis methods. J Cereal Sci 33:39-52

Giraldo P, Rodriguez-Quijano M, Simon C, Vazquez JF, Carrillo JM (2010) Allelic variation in HMW glutenins in Spanish wheat landraces and their relationship with bread quality. Span J Agri Res 8:1012-1023. doi:10.5424/sjar/2010084-1394

Gupta RB, MacRitchie F (1994) Allelic variation at glutenin subunit and gliadin loci, Glu-1, Glu-3 and Gli-1 of common wheats. II. Biochemical basis of the allelic effects on dough properties. J Cereal Sci 19:19-29. doi:10.1006/jcrs.1994.1004

Gupta RB, Shepherd KW (1988) Low-molecular weight glutenin subunits in wheat: their variation inheritance and association with bread-making quality. In: Miller TE, Koebner RMD (ed) Proceedings of the 7th International Wheat Genetics Symposium, Institute of Plant Science Research, Cambridge, pp 943-949

Gupta RB, Shepherd KW (1990) Two-step one-dimensional SDSPAGE analysis of LMW subunits of glutenin. I. Variation and genetic control of the subunits in hexaploid wheats. Theor Appl Genet 80:65-74. doi:10.1007/BF00224384

Gupta RB, Singh NK, Shepherd KW (1989) The cumulative effect of allelic variation in LMW and HMW glutenin subunits on dough properties in the progeny of two bread wheats. Theor Appl Genet 77:57-64. doi:10.1007/BF00292316

Gupta RB, Bekes F, Wrigley CW, Moss HJ (1990) Prediction of wheat quality in breeding on the basis of LMW and HMW glutenin subunit composition. In: O'Brien L, Ellison FW, Hare RA, Mackay MC (eds) Proceedings of the 6th Wheat Breeding Society of Australia (Inc), Tamworth, Australia, pp 217-225

Gupta RB, Békés F, Wrigley CW (1991) Prediction of physical dough properties from glutenin subunit composition in bread wheats: correlation studies. Cereal Chem 68:328-333

Gupta RB, Paul JG, Cornish GB, Palmer GA, Bakes F, Rathjen AJ (1994) Allelic variation at glutenin subunit and gliadin loci, Glu1, Glu-3 and Gli-1 of common wheats. I. Its additive and interaction effects on dough properties. J Cereal Sci 19:9-17. doi:10.1006/jcrs.1994.1003

He ZH, Liu L, Xia XC, Liu JJ, Pena RJ (2005) Composition of HMW and LMW glutenin subunits and their eVects on dough 
properties, pan bread, and noodle quality of Chinese bread wheats. Cereal Chem 82:345-350. doi:10.1094/CC-82-0345

Henkrar F, El-Haddoury J, Ouabbou H, Nsarellah N, Iraqi D, Bendaou N, Udupa SM (2015a) Genetic diversity and its temporal changes in improved bread wheat cultivars of Morocco. Rom Agric Res 32:19-25. http://www.incda-fundulea.ro/rar/ nr32/rar32.3.pdf. Accessed on 27 July 2017

Henkrar F, El-Haddoury J, Ouabbou H, Nsarellah N, Iraqi D, Bendaou N, Udupa SM (2015b) Genetic diversity reduction in improved durum wheat cultivars of Morocco as revealed by microsatellite markers. Sci Agric 73:134-141. doi:10.1590/ 0103-9016-2015-0054

Henkrar F, El-Haddoury J, Ouabbou H, Bendaou N, Udupa SM (2016) Genetic characterization of Moroccan and the exotic bread wheat cultivars using functional and random DNA markers linked to the agronomic traits for genomics-assisted improvement. 3. Biotech 6:97. doi:10.1007/s13205-016-0413-y

Jackson EA, Holt LM, Payne PI (1983) Characterisation of highmolecular-weight gliadin and low-molecular-weight glutenin subunits of wheat endosperm by two-dimensional electrophoresis and chromosomal localisation of their controlling genes. Theor Appl Genet 66:29-37. doi:10.1007/BF00281844

Jlibene M, Mergoum M, Belhadri M, Mekni M, Smith E (1996) La varièté du blé tendre "Tilila" combine souplesse et productivité. Al Awamia 92:7-14

Lafiandra D, Tucci GF, Pavoni A, Turchetta T, Margiotta B (1997) PCR analysis of x- and y-type genes present at the complex GluA1 locus in durum and bread wheat. Theor Appl Genet 94:235-240. doi:10.1007/s001220050405

Lei ZS, Gale KR, He ZH, Gianibelli MC, Larroque O, Xia XC, Butow BJ, Ma WJ (2006) Y-type gene specific markers for enhanced discrimination of high-molecular-weight glutenin alleles at the Glu-B1 locus in hexaploid wheat. J Cereal Sci 43:94-101. doi:10.1016/j.jcs.2005.08.003

Lerner SE, Kolman MA, Rogers WJ (2009) Quality and endosperm storage protein variation in Argentinean grown bread wheat. I. Allelic diversity and discrimination between cultivars. J Cereal Sci 49:337-345. doi:10.1016/j.jcs.2008.04.003

Liu K, Muse SV (2005) PowerMarker: an integrated analysis environment for genetic marker analysis. Bioinformatics 21:2128-2129. doi:10.1093/bioinformatics/bti282

Lhaloui S, El-Bouhssini M, Nsarellah N, Nachit MM, Amri A (2000) Biotic stress limiting durum wheat production in MoroccoHessian fly and the Russian wheat aphid: Surveys, loss assessment and identification of sources of resistance. In: Royo C, Nachit M, Di Fonzo N, Araus JL (eds) Durum wheat improvement in the Mediterranean region: new challenges. CIHEAM, Zaragoza, pp. 373-379. http://om.ciheam.org/article. php?IDPDF=600061. Accessed on 26 July 2017

Lhaloui S, El Bouhssini M, Naserlhaq N, Amri A, Nachit M, El Haddoury J, Jlibène $M$ (2005) Les cécidomyies des céréales au Maroc: Biologie, dégâts et moyens de lutte. INRA - Rabat, Maroc, pp. 43-51

Luo C, Griffin WB, Branlard G, McNeil DL (2001) Comparison of low- and high molecular-weight wheat glutenin allele effects on flour quality. Theor Appl Genet 102:1088-1098. doi:10.1007/ s001220000433

Ma W, Zhang W, Gale KR (2003) Multiplex-PCR typing of high molecular weight glutenin alleles in wheat. Euphytica 134:51-60. doi:10.1023/A:1026191918704

Masci S, Rovelli L, Kasarda DD, Vensel WH, Lafiandra D (2002) Characterisation and chromosomal localization of C-type low molecular-weight glutenin subunits in the bread wheat cultivar Chinese Spring. Theor Appl Genet 104:422-428. doi:10.1007/ s001220100761
Metakovsky EV, Wrigley CW, Bekes F, Gupta RB (1990) Gluten polypeptides as useful genetic markers of dough quality in Australian wheats. Aust J Agr Res 41:289-306. doi:10.1071/ AR9900289

Odenbach W, Mahgoub El-S (1988) Relationships between HMW glutenin subunit composition and the sedimentation value in reciprocal sets of inbred backcross lines derived from two winter wheat crosses. In: Proceedings of 7 th International Wheat Genetics Symposium, Cambridge, England, pp 987-991

Payne PI (1987) Genetics of wheat storage proteins and the effects of allelic variation on breadmaking quality. Ann Rev Plant Physiol 38:141-153. doi:10.1146/annurev.pp.38.060187.001041

Ram S (2003) High molecular weight glutenin subunit composition of Indian wheats and their relationships with dough strength. J Plant Biochem Biotechnol 12:151-155. doi:10.1007/BF03263177

Saghai-Maroof MA, Soliman KM, Jorgensen RA, Allard RW (1984) Ribosomal DNA spacer-length polymorphisms in barley: mendelian inheritance, chromosomal location, and population dynamics. Proc Nat Acad Sci 81(24):8014-8018

Shan X, Clayshulte SR, Haley SD, Byrne PF (2003) Variation for glutenin and waxy alleles in the US hard winter wheat germplasm. J Cereal Sci 37:129-137. doi:10.1016/j.jcs.2006.09.007

Shan X, Clayshulte SR, Scott D, Haley SD, Byrne PF (2007) Variation for glutenin and waxy alleles in the US hard winter wheat germplasm. J Cereal Sci 45:199-208. doi:10.1016/j.jcs. 2006.09.007

Shewry PR, Halford NG, Tatham AS (1992) High molecular weight subunits of wheat glutenin. J Cereal Sci 15:105-120. doi:10. 1016/S0733-5210(09)80062-3

Tabasum A, Iqbal N, Hameed A, Arshad R (2011) Evaluation of Pakistani wheat germplasm for bread quality based on allelic variation in hmw glutenin subunits. Pak J Bot 43:1735-1740

Tamura K, Peterson D, Peterson N, Stecher G, Nei M, Kumar S (2011) MEGA5: molecular evolutionary genetics analysis using maximum likelihood, evolutionary distance, and maximum parsimony methods. Mol Biol Evol 28:2731-2739. doi:10. 1093/molbev/msr121

Terasawa Y, Takata K, Hirano H, Kato K, Kawahara T, Sasakuma T, Sasanuma T (2011) Genetic variation of high-molecular-weight glutenin subunit composition in Asian wheat. Genet Resour Crop Evol 58:283-289. doi:10.1007/s10722-010-9573-5

Udupa SM, Robertson LD, Weigand F, Baum M, Kahl G (1999) Allelic variation at (TAA) microsatellite loci in a World Collection of Chickpea (Cicer arietinum L) Germplasm. Mol Gen Genet 261:354-363. doi:10.1007/s004380050976

Veraverbeke WS, Delcour JA (2002) Wheat protein composition and properties of wheat glutenin in relation to bread-making functionality. Crit Rev Food Sci Nutr 42:179-208. doi:10. 1080/10408690290825510

Wang LH, Zhao XL, He ZH, Ma W, Appels R, Peña RJ, Xia XC (2009) Characterization of low-molecular-weight glutenin subunit Glu-B3 genes and development of STS markers in common wheat (Triticum aestivum L.). Theor Appl Genet 118:525-539. doi:10.1007/s00122-008-0918-9

Yan ZH, Dai SF, Liu DC, Wei YM, Zheng YL (2007) Allelic variation of high molecular weight glutenin sub units in hexaploid wheat landraces of Tibet, China. Int J Agric 2:838-843. doi:10.3923/ijar.2007.838.843

Zarkti H, Ouabbou H, Hilali A, Udupa SM (2010) Detection of genetic diversity in Moroccan durum wheat accessions using agro-morphological traits and microsatellite markers. Afr J Agric Res 5:1837-1844. doi:10.5897/AJAR09.249

Zhang W, Gianibelli MC, Rampling L, Gale KR (2004) Characterisation and marker development for low molecular weight glutenin genes from Glu-A3 alleles of bread wheat (Triticum 
aestivum L.). Theor Appl Genet 108:1409-1419. doi:10.1007/ s00122-003-1558-8

Zhao XL, Ma W, Gale KR, Lei ZS, He ZH, Sun QX, Xia XC (2007a) Identification of SNPs and development functional markers for LMW-GS genes at Glu-D3 and Glu-B3 loci in bread wheat (Triticum aestivum L.). Mol Breed 20:223-231. doi:10.1007/ s11032-007-9085-y
Zhao XL, Xia XC, He ZH, Lei ZS, Appels R, Yang Y, Sun QX, Ma W (2007b) Novel DNA variations to characterize low molecular weight glutenin Glu-D3 genes and develop STS markers in common wheat. Theor Appl Genet 114:451-460. doi:10.1007/ s00122-006-0445-5 